Attadrib: Jurnal Pendidikan Guru Madrasah Ibtidaiyah

(p-ISSN: 2599-3194 |e-ISSN: On Process

Volume 3, Issue. 02, 2020, pp. 9-18

\title{
Pengembangan Buku Ajar Berbasis HOTS Dimensi Taksonomi Bloom Tema 8 Subtema 1 Kelas 4
}

\author{
Wahyuni Mariana*1, Benny Angga Permadi². \\ ${ }^{1}$ Institut pesantren Kh. Abdul chalim, mojokerto, Indonesia \\ ${ }^{2}$ Institut pesantren Kh. Abdul chalim, mojokerto, Indonesia \\ e-mail: rwahyuni61@gmail.com, bennyangga68@gmail.com
}

Submitted: 06-07-2020Ｒevised : 18-07-2020Ａccepted: 27-08-2020

\begin{abstract}
Abtrak. Penelitian bertujuan untuk menyusun buku ajar berbasis HOTS dimensi Taksonomi Bloom untuk siswa Kelas 4 di MI Dwi Dasa Warsa. Pengembangan buku ini terbatas pada mata pelajaran tematik yaitu tema 8 subtema 1 kelas 4 . Penelitian ini merupakan penelitian Research and Development dengan pendekatan model pengembangan 4-D Model Thiagarajan yang memiliki 4 tahap, yaitu Define (Pendefinisian), Design (Perancangan), Develop (Pengembangan) dan Disseminate (Penyebaran). Buku ajar ini divalidasi oleh 2 ahli materi (dosen ahli materi dan guru mata pelajaran), 1 ahli media dan 24 siswa yang menjadi objek penelitian. Buku ajar diuji cobakan pada 24 siswa kelas 4 MI Dwi Dasa Warsa. Pengumpulan data menggunakan teknik wawancara kepada guru mata pelajaran dan siswa kelas 4. Hasil penelitian menunjukkan bahwa buku ajar ini secara keseluruhan layak digunakan sebagai bahan ajar. Hal tersebut ditunjukkan dengan hasil validasi oleh dosen ahli materi dengan total skor (X) lebih besar dari total skor pembanding $(138>104,95)$ dan masuk dalam kategori nilai A (sangat baik) dan hasil validasi oleh guru mata pelajaran dengan total skor (X) lebih besar dari total skor pembanding $(167>104,95)$ dan masuk dalam kategori nilai A atau sangat baik. Sedangkan hasil validasi oleh ahli media mendapat total skor (X) lebih besar dari total skor pembanding $(106>72)$ termasuk kategori nilai A atau sangat baik. Validasi oleh siswa dengan penghitungan SPSS Person Correlation menunjukkan semua skor telah mencapai lebih dari 0,05 dan bisa dikatakan valid.
\end{abstract}

Kata kunci: Buku ajar, Tematik, Hots

\begin{abstract}
The research aimed to compile HOTS textbooks based on Bloom's Taxonomy dimensions for grade 4 students at MI Dwi Dasa Warsa. The development of this book is limited to thematic subjects, namely the theme of 8 sub-themes 1 class 4. This research is a Research and Development research with a 4-D development model approach to the Thiagarajan Model which has 4 stages, namely Define, Design, and Develop (Development) and Disseminate (Spread). This textbook was validated by 2 material experts (subject matter expert lecturers and subject teachers), 1 media expert and 24 students who were the research objects. Textbooks were tested on 24 grade 4 students of MI Dwi Dasa Warsa. Data collection used interview techniques to subject teachers and grade 4 students. The results showed that this textbook as a whole was suitable for use as teaching materials. This is indicated by the results of the validation by the material expert lecturer with a total score $(X)$ greater than the total comparison score (138> 104.95) and is included in the category $A$ value (very good) and the validation results by the subject teacher with a total score $(X)$ is greater than the total comparison score $(167>104.95)$ and is in the category $A$ score or very good. Meanwhile, the results of the validation by media experts got a total score (X) greater than the total comparison score $(106>72)$ which was categorized as $A$ or very good. Validation by students with the calculation of SPSS Person Correlation shows that all scores have reached more than 0.05 and can be said to be valid
\end{abstract}

Keywords: Textbooks, HOTS, Thematic.

https://doi.org/10.31538/attadrib.v3i2.105

How to Cite Mariana, W., \& Permadi, B. A. (2020). Pengembangan Buku Ajar Berbasis Hots Dimensi Taksonomi Bloom Tema 8 Subtema 1 Kelas 4. Attadrib: Jurnal Pendidikan Guru Madrasah Ibtidaiyah, 3(2), 9-18 


\section{PENDAHULUAN}

Sistem kurikulum di Indonesia telah mengalami perubahan beberapa kali dan kurikulum terbaru di Indonesia adalah Kurikulum 2013 (K13)(Abidin, 2014; Agustinus, 2014; Bahrissalim \& Fauzan, 2018). Kurikulum tersebut diberlakukan oleh pemerintah sejak tahun 2013 . Menurut Wakil Menteri Pendidikan, Musliar Kasim, menjelaskan dalam paparannya mengenai Kurikulum 2013, menjelaskan bahwa pada Kurikulum 2013 memuat sebuah tujuan pembelajaran siswa yang tidak hanya pintar dan memahami materi pembelajaran, tapi juga bisa mewujudkan siswa menjadi insan yang kreatif, produktif, inovatif serta afektif melalui penguatan keterampilan, sikap, dan pengetahuan yang terintegrasi (Katuuk, 2014; Maarif \& Rofiq, 2018). Hal itu juga sebagai upaya pemerintah dalam mewujudkan UU No.20 tahun 2003 tentang sistem pendidikan di Indonesia.

Pada saat ini, hampir seluruh sekolah Madrasah Ibtidaiyah terutama yang sudah terakreditasi A telah menggunakan Kurikulum 2013 atau Kurikulum Berbasis Tematik(Permadi \& Adityawati, 2018). Termasuk di sekolah MI Dwi Dasa Warsa yang akan menjadi tempat tujuan peneliti juga telah menerapkan kurikulum tersebut. Pada prakteknya, sekolah MI Dwi Dasa Warsa telah menggunakan Kurikulum 2013 pada seluruh pembelajarannya. Begitu pula dengan buku ajarnya juga telah menggunakan buku yang berbasis Kurikulum 2013 yang didalamnya telah terintegrasi dengan beberapa soal HOTS (High Order Thinking Skill). Tapi pada prakteknya masih menggunakan pembelajaran secara klasikal. Hal tersebut dikarenakan guru sebagai pengajar masih belum mampu sepenuhnya melakukan pembelajaran berbasis HOTS.

High Order Thinking Skill (HOTS) adalah suatu pendekatan pembelajaran yang menuntut siswa untuk berpikir tingkat tinggi dalam menyelesaikan suatu persoalan. Karena dengan berpikir tingkat tinggi, dapat mendorong siswa untuk berlatih berpikir secara mendalam dan luas terhadap materi pelajaran (Ibrahim et al., 2020). Pendekatan HOTS yang dipakai biasanya menggunakan pendekatan HOTS berbasis Dimensi Taksonomi Bloom. Pada Dimensi Taksonomi Bloom, kemampuan siswa dibagi menjadi 6 tingkatan yaitu biasanya disebut C1, C2, C3, C4, C5 dan C6. Mulai dari kemampuan yang paling dasar yaitu mengingat, memahami, mengaplikasikan, menganalisis, mengevaluasi dan terakhir pada kemampuan paling tinggi yaitu mencipta. Pembelajaran HOTS bukan hanya menuntut siswa untuk kritis, kreatif dan analitis tapi juga menuntut guru untuk bisa kreatif dalam membuat soal.

Berlatar belakang hal tersebut, peneliti mengembangkan bahan ajar berupa Buku Ajar Berbasis HOTS Dimensi Taksonomi Bloom Tema 8 Subtema 1 Kelas 4. Pengembangan tersebut akan dilakukan di kelas 4 pada mata pelajaran Tema 8 Subtema 1. Orisinalitas dalam penelitian ini dibuktikan berdasarkan hasil penelitian terdahulu berupa beberapa skripsi yang berkaitan dengan judul penelitian ini. Adapun beberapa skripsi tersebut antara lain:

Pertama, Skripsi yang ditulis oleh Ferina Widya Wiyanti. Skripsi tersebut berjudul "Pengembangan Paket Tes Matematika Kemampuan Berpikir Tingkat Tinggi Siswa pada Siswa SMP”. Hasil penelitian dari skripsi tersebut menyatakan bahwa berdasarkan hasil analisa data dan hasil uji serta wawancara yang telah dilakukan oleh peneliti pada uji coba one to one dan kelas besar, dapat dikatakan bahwa tes kemampuan berpikir tingkat tinggi yang dikembangkan dapat mengorganisasikan siswa dalam berpikir diatas level mengaplikasi, yaitu level menganalisis (C4), mengevaluasi (C5) dan mencipta (C6)(Lestari et al., 2016).

Kedua, Skripsi yang ditulis oleh Afsari A.S. Skripsi tersebut berjudul "Pengembangan Lembar Kerja Peserta Didik (LKPD) Berpikir Tingkat Tinggi pada Pokok Bahasan Sel Kelas XI IPA SMA Negeri 16 Makassar". Hasil penelitian dari skripsi tersebut menyatakan bahwa berdasarkan uji coba terhadap kevalidan LKPD yang telah dikembangkan, ada pada kategori valid dengan nilai rata-rata pada semua aspek penilaian sebesar 3,55. Siswa lebih dari 50\% telah memberikan respon positif pada LKS berpikir tingkat tinggi yang sudah dikembangkan. Hal ini menandakan bahwa LKPD berpikir tingkat tinggi yang sudah dikembangkan sudah efektif untuk digunakan dalam proses pembelajaran(AS, 2017). 
Ketiga, Jurnal yang ditulis oleh (Teti et al., n.d.). Jurnal tersebut berjudul "Pengembangan Lembar Kerja Siswa Berbasis HOTS Berdasarkan Taksonomi Bloom di Sekolah Dasar". Hasil dari penelitian pada jurnal tersebut menyatakan bahwa, pengembangan kemampuan Higher Order Thinking Skill pada pelaksanaan pendidikan di Indonesia didasarkan pada Taksonomi Bloom. Produk lembar kerja siswa yang dirancang mencakup seluruh materi pada mata pelajaran Tema. Hasil yang diperoleh setelah dilakukan validasi oleh tim ahli dan direvisi kekurangan lembar kerja siswa, kemudian dilanjutkan dengan uji coba sebanyak dua kali, yaitu pada uji coba pertama dan uji coba kedua. Pada uji coba pertama dan uji coba kedua, respons siswa terhadap penggunaan lembar kerja siswa pertama tidak jauh berbeda. $81,3 \%$ siswa memahami materi dan meningkat menjadi rata-rata 95\% siswa memahami isi LKS. Sedangkan hasil dari uji coba kedua yang kemudian direvisi menjadi produk akhir lembar kerja siswa berbasis High Order Thinking Skill Taksonomi Bloom.

Keempat, Jurnal yang ditulis oleh Nurul Yuliandini, Ghullam Hamdu dan Resa Respati. Jurnal tersebut berjudul "Pengembangan Soal Tes Berbasis Higher Order Thinking Skill (HOTS) Taksonomi Bloom Revisi di Sekolah Dasar". Hasil dari penelitian dan pengembangan pada jurnal tersebut menyatakan bahwa, soal tes telah layak digunakan untuk sekolah dasar, sedangkan pada validasi eksternal telah dinyatakan secara keseluruhan hasil dari pengujian menggunakan rumus product moment butir soal telah dinyatakan valid. Penentuan reliabilitas dengan menggunakan formula alpha Cronbach memiliki nilai reliabilitas sebesar 0,763 yang dikategorikan reliabel. Hasil yang diperoleh secara keseluruhan dalam penelitian pengembangan ini bahwa soal tes kemampuan berpikir tingkat tinggi dikatakan valid dan reliable.

Kelima, Jurnal yang ditulis oleh (Fanani \& Kusmaharti, 2018). Jurnal tersebut berjudul "Pengembangan Pembelajaran Berbasis HOTS (Higher Order Thinking Skill) di Sekolah Dasar Kelas V'. Hasil dari penelitian pada jurnal tersebut menyatakan bahwa berdasarkan hasil uji coba terbatas menunjukkan bahwa hasil pengembangan pembelajaran keterampilan berpikir tingkat tinggi (HOTS) mampu menghasilkan hasil belajar total (91\%) dalam pembelajaran 1, Sub-tema 3, Peristiwa Manusia dan Alam, Tema Kegiatan dalam Kehidupan kelas V di Sekolah Dasar

\section{METODE PENELITIAN}

Adapun penelitian pengembangan buku ajar Berbasis HOTS Dimensi Taksonomi Bloom Tema 8 Subtema 1 Kelas 4 MI Dwi Dasa Warsa Trawas Mojokerto, peneliti menggunakan 4-D Model yaitu suatu model pengembangan perangkat pembelajaran dari Thiagarajan. Model pengembangan ini disarankan oleh Silvasailam Thiagarajan, Dorothy S.Semmel dan Melvyn I.Semmel. Sesuai dengan singkatannya yaitu 4-D Model, model pengembangan ini terdiri dari empat tahap yaitu, Define (Pendefinisian), Design (Perancangan), Develop (Pengembangan) dan Disseminate (Penyebaran).

Prosedur Penelitian dan Pengembangan: Berdasarkan model penelitian 4-D Model yang akan dilakukan peneliti dalam penelitian dan pengembangannya, berikut akan disajikan prosedur penelitiannya. Jenis PenelitiaN: Jenis penelitian ini adalah penelitian dan pengembangan (Research and Development). Penelitian dan pengembangan adalah suatu metode penelitian dimana peneliti melakukan suatu penelitian untuk menghasilkan atau mengembangkan suatu produk yang dapat diuji efektifitas dan validitasnya.

Waktu dan Lokasi Penelitian: Penelitian akan dilakukan pada semester genap setelah pelaksanaan ulangan tengah semester tahun ajaran 2018/2019. Lokasi penelitian akan dilakukan di MI Dwi Dasa Warsa Trawas Mojokerto. Subjek uji coba hasil penelitian dan pengembangan adalah siswa kelas 4A sejumlah 24 siswa di sekolah tersebut.

Berdasarkan Peraturan Pemerintah No. 19 Tahun 2005 tentang Standar Nasional Pendidikan, pemerintah menetapkan bahwa buku teks pelajaran yang akan digunakan harus dinilai 
terlebih dahulu kelayakan isi, bahasa, penyajian dan kegrafikaannya oleh BSNP dan ditetapkan dengan Peraturan Menteri (PP 19 th 2005 pasal 43 ayat (5). Berdasarkan hal tersebut,maka peneliti menggunakan instrumen penilaian dari ahli materi buku ajar, media buku ajar dan penilaian siswa terhadap buku ajar. Teknik wawancara menggunakan wawancara semi terstruktur. Peneliti tidak terlalu berpedoman pada pertanyaan yang telah disusun. Hal tersebut dilakukan agar peneliti memperoleh jawaban yang lebih luas. Soal Pre-test dan Post-test (evaluasi akhir pembelajaran) dibuat peneliti untuk mengetahui peningkatan hasil belajar siswa setelah menggunakan buku ajar yang telah dikembangkan.

Teknik yang digunakan peneliti dalam analisis data adalah menggunakan teknik analisis deskriptif kuantitatif, yaitu memaparkan hasil pengembangan produk yang berupa buku ajar setelah diimplementasikan, diuji tingkat validasinya dan kelayakan produk. Analisis hasil penilaian validasi produk oleh ahli materi dan ahli media menggunakan rumus yang diadaptasi dari Saifuddin Azwar dalam Penelitian S2 Tesis, (Agustyarini \& Jailani, 2015) dengan judul "Pengembangan Bahan Ajar Matematika dengan Pendekatan Kontekstual dan Metode Penemuan Terbimbing untuk Meningkatkan EQ dan SQ Siswa Akselerasi di SMP/MTs".

Angket validasi siswa berupa pernyataan dan pada setiap pernyataan akan diberi skor seperti pada tabel 3.6. Data yang telah diperoleh melalui angket oleh siswa tersebut berupa nilai kuantitatif dan akan dihitung menggunakan SPSS yaitu untuk mengetahui Valid Reliable dari data yang telah diperoleh. Data bisa dikatakan valid dan reliabel jika telah mencapai skor $>0,05$ (lebih dari 0,05).

$\begin{array}{lc}\text { Keterangan } & \text { Skor Pernyataan } \\ \text { SS (Sangat Setuju) } & 5 \\ \text { S (Setuju) } & 4 \\ \text { CS (Cukup Setuju) } & 3 \\ \text { TS (Tidak Setuju) } & 2 \\ \text { STS (Sangat Tidak Setuju) } & 1\end{array}$

Analisis hasil belajar diperoleh dari hasil perbandingan nilai pre-test dan post-test untuk mengetahui pengaruh buku ajar terhadap nilai hasil belajar siswa. Penghitungan ini menggunakan SPSS dengan rumus Paired Sample T Test. Selain menggunakan rumus tersebut, analisis pengaruh buku ajar pada hasil belajar juga dilihat dari jika hasil post-test atau hasil evaluasi siswa $80 \%$ telah mencapai nilai KKM. Adapun nilai KKM untuk pembelajaran Tema kelas 4 di MI Dwi Dasa Warsa adalah 70 .

Penentuan kualitas hasil pengembangan perangkat pembelajaran umumnya diperlukan tiga kriteria menurut (Plomp \& Nieveen, 2010) yang menyatakan bahwa, "Validitiy : Relevance (there is a need for the intervention and its design is based on state-ofthe-art (scientific) knowledge) and Consistency (The intervention is 'logically' designed). Practicality: The intervention is realistically usable in the settings for which it has been designed and developed. Effectiveness : Using the intervention results in desired outcomes. Berdasarkan pernyataan tersebut, kriteria kualitas media pembelajaran ditentukan dari kevalidan (validity), kepraktisan (practicality), dan keefektifan (effectiveness).

Kevalidan (Validity). Kevalidan dalam suatu pengembangan bahan ajar dibedakan dalam dua hal yaitu relevansi dan konsistensi bahan ajar. Adapun kualitas relevansi dan konsistensi bahan ajar diperoleh peneliti dari hasil validitas oleh ahli media dan ahli materi. Kepraktisan (Practicality). Kepraktisan bahan ajar dapat dilihat dari selama penggunaan bahan ajar yang yang dikembangkan itu sendiri. Adapun kriteria kepraktisan ini diperoleh peneliti dari hasil validasi siswa setelah menggunakan bahan ajar. Keefektifan (Effectiveness). Keefektifan bahan ajar dapat diketahui pada hasil akhir belajar siswa. Adapun kriteria keefektifan ini diperoleh peneliti dari perbandingan hasil pre-test dan post-test siswa dan perbandingan hasil belajar $80 \%$ siswa telah mencapai nilai sesuai KKM. 


\section{RESULT AND DISCUSSION}

\section{Result}

Pada tahap awal pengumpulan data, peneliti melakukan wawancara dengan guru pengampu mata pelajaran dan siswa kelas 4 di MI Dwi Dasa Warsa. Selain dengan wawancara, peneliti juga melakukan observasi pada kelas yang akan diteliti, dalam hal ini kelas 4A. Berdasarkan wawancara dan observasi tersebut, telah diperoleh permasalahan-permasalahan yang telah dijelaskan pada latar belakang di BAB I. Berdasarkan permasalahan yang ditemukan pada BAB I tersebut, peneliti memberi solusi yaitu dengan berupa buku ajar berbasis HOTS Dimensi Taksonomi Bloom untuk pembelajaran mata pelajaran Tematik pada kelas 4 khususnya Tema 8 Subtema 1.

Pelaksanaan pengembangan produk ini, dilakukan oleh peneliti berdasarkan tahapantahapan dengan metode penelitian dan pengembangan 4-D Model dari (Kurniawan \& Dewi, 2017; Lev \& Thiagarajan, 1993; Thiagarajan \& And Others, 1974). Adapun alur tahapannya digambarkan pada bagan berikut.

\section{Gambar 1. Pengembangan 4-D Model Thiagarajan}

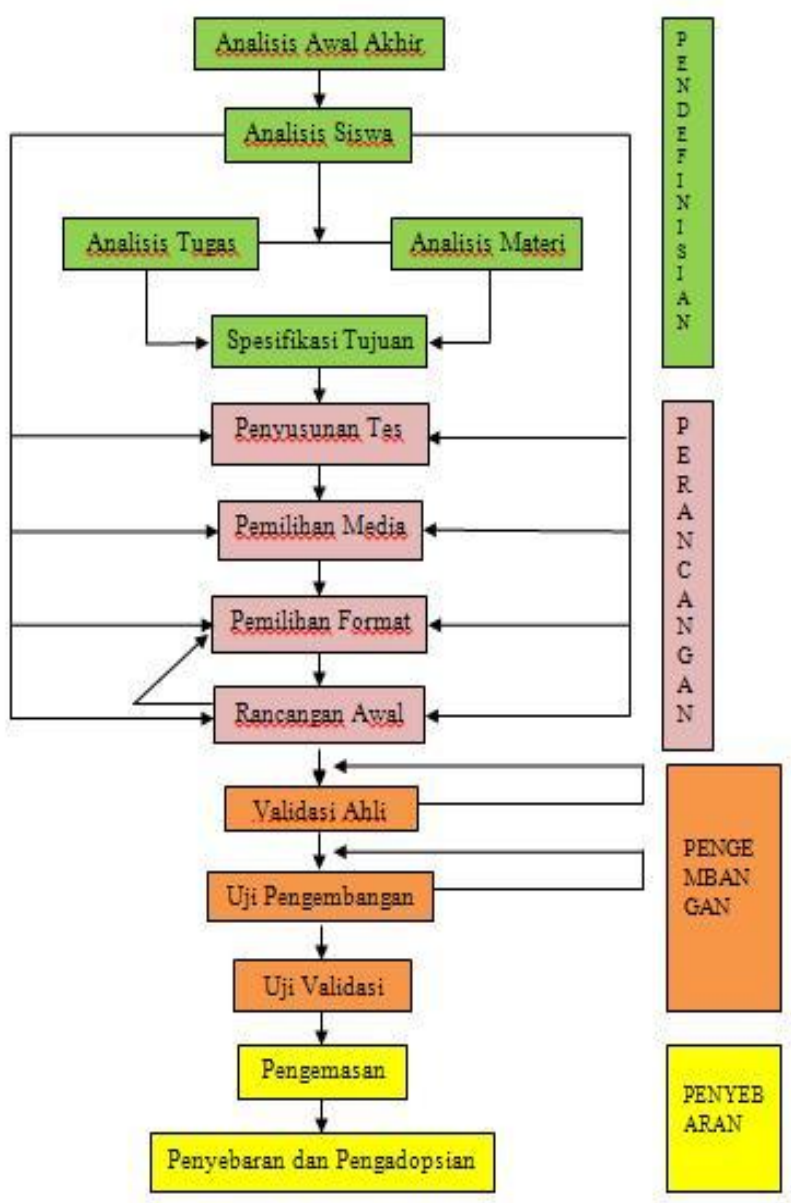

Tahap 1 : Define (Pendefinisian) a) Analisis awal-akhir. Pada langkah pertama ini peneliti telah menganalisis masalah dasar yang ada di lapangan. b) Analisis siswa. Hasil analisis siswa diperoleh peneliti dari hasil wawancara kepada siswa mengenai kegiatan pembelajaran dan dengan melihat hasil belajar siswa dalam hal ini yaitu hasil pre-test. Dari hasil pre-test tersebut diketahui bahwa masih ada beberapa siswa yang belum mencapai nilai sesuai KKM yang ditentukan. c) Analisis tugas. Analisis tugas dilakukan peneliti untuk menganalisis Kompetensi Inti dan 
Kompetensi Dasar terkait materi yang dikembangkan. Dari hasil analisis tersebut, peneliti telah memilih Kompetensi Inti dan Kompetensi Dasar dari Tema 8 Subtema 1 dengan muatan mata pelajaran Bahasa Indonesia, IPA, IPS dan PPKN. d) Analisis materi. Analisis materi ini didasarkan oleh peneliti dengan melihat KI dan KD serta materi pelajaran yang bisa dikembangkan dengan pembelajaran HOTS Dimensi Taksonomi Bloom. Untuk penjelasan tentang materi telah dijelaskan peneliti pada BAB II. E) Spesifikasi tujuan. Spesifikasi tujuan pembelajaran telah dilakukan peneliti dengan menentukan indikator pencapaian pembelajaran yang telah dicantumkan dalam buku ajar yang dikembangkan.

Tahap 2 : Design (Perancangan): 1) Penyusunan Tes. Tes telah diberikan oleh peneliti dalam bentuk pre-test dan post-test. Adapun soal-soal pre-test dan post-test telah dilampirkan peneliti pada bagian lampiran. 2) Pemilihan media. Penggunaan media yang relevan telah dilakukan peneliti selama proses pembelajaran menggunakan buku ajar yang dikembangkan. 3) Pemilihan format. Pemilihan format berupa desain layout, gambar dan tulisan. Pemilihan format ini akan dijelaskan pada rancangan awal. 4) Rancangan awal. Berikut adalah beberapa rancangan awal yang dibuat oleh peneliti beserta catatan revisi dari validator ahli media dan materi.

\section{Analisis Data}

Analisis data diperoleh peneliti dari hasil validasi produk oleh ahli materi dan media, hasil validasi produk oleh siswa dan analisis hasil belajar (pre-test dan post-test). Analisis data berikut ini adalah proses ketiga dalam tahap penelitian dan pengembangan 4-D Model yaitu tahap pengembangan (Develop) yang mencakup uji validasi dan uji pengembangan hasil produk setelah digunakan oleh siswa. Berikut akan dijelaskan lebih rinci untuk analisis data dari masing-masing hasil analisis. Hasil Analisis Validasi Produk oleh Ahli Materi (Dosen dan Guru). Setelah penghitungan analisis data akan dimasukkan kedalam skala 5 atau lima kriteria seperti yang dijelaskan pada metode penelitian.

Tabel 1. Hasil analisis skala 5 atau lima kriteria (dosen ahli materi)

\begin{tabular}{|c|c|c|}
\hline Interval Skor & ilai & Kategori \\
\hline $138>70+1,5(23,3)$ & 1 & Sangat baik \\
\hline $70+0,5(23,3)<138 \leq 70+1,5(23,3)$ & ] & Baik \\
\hline $70-0,5(23,3)<138 \leq 70+0,5(23,3)$ & 1 & Cukup baik \\
\hline $70-1,5(23,3)<138 \leq 70-0,5(23,3)$ & ] & Kurang baik \\
\hline $138 \leq 70-1,5(23,3)$ & ] & Tidak baik \\
\hline
\end{tabular}

Berdasarkan data di atas, diketahui bahwa total skor (X) diperoleh sebesar 138. Dari skor tersebut kemudian dibandingkan dengan hasil perhitungan rata-rata skor ideal ( sebesar 70 ditambah 1,5 dikalikan dengan simpangan baku ideal (SB sebesar 23,3. Dari perhitungan tersebut menghasilkan total skor pembanding 104,95. Jadi, dapat disimpulkan bahwa, total skor (X) lebih besar dari total skor pembanding $(138>104,95)$ dan masuk dalam kategori nilai A atau sangat baik.

Tabel 2. Hasil analisis skala 5 atau lima kriteria (guru mata pelajaran)

\begin{tabular}{ccc}
\hline Interval Skor & ] & Kategori \\
& ilai & \\
\hline $167>\mathbf{7 0}+\mathbf{1 , 5 ( 2 3 , 3 )}$ & & Sangat baik \\
$\mathbf{7 0 + 0 , 5 ( 2 3 , 3 )}<\mathbf{1 6 7} \leq \mathbf{7 0}+\mathbf{1 , 5 ( 2 3 , 3 )}$ & ] & Baik \\
\hline
\end{tabular}




\begin{tabular}{ccc}
\hline $70-0,5(23,3)<167 \leq 70+0,5(23,3)$ & Cukup baik \\
$70-1,5(23,3)<167 \leq 70-0,5(23,3)$ & ] & Kurang baik \\
$167 \leq 70-1,5(23,3)$ & ] & Tidak baik \\
\hline
\end{tabular}

Berdasarkan data di atas, diketahui bahwa total skor $(\mathrm{X})$ diperoleh sebesar 167. Dari skor tersebut kemudian dibandingkan dengan hasil perhitungan rata-rata skor ideal ( sebesar 70 ditambah 1,5 dikalikan dengan simpangan baku ideal (SB sebesar 23,3. Dari perhitungan tersebut menghasilkan total skor pembanding 104,95. Jadi, dapat disimpulkan bahwa, total skor (X) lebih besar dari total skor pembanding $(167>104,95)$ dan masuk dalam kategori nilai A atau sangat baik.

\section{Hasil Analisis Validasi Produk oleh Ahli Media}

Setelah penghitungan analisis data akan dimasukkan kedalam skala 5 atau lima kriteria seperti yang dijelaskan pada metode penelitian.

Tabel 3. Hasil analisis skala 5 atau lima kriteria ahli media

\begin{tabular}{ccc}
\hline Interval Skor & jlai & Kategori \\
\hline $106>48+1,5(16)$ & & Sangat baik \\
$48+0,5(16)<106 \leq 48+1,5(16)$ & ] & Baik \\
$48-0,5(16)<106 \leq 48+0,5(16)$ & 1 & Cukup baik \\
$48-1,5(16)<106 \leq 48-0,5(16)$ & ] & Kurang baik \\
$106 \leq 48-1,5(16)$ & ] & Tidak baik \\
\hline
\end{tabular}

Berdasarkan data di atas, diketahui bahwa total skor (X) diperoleh sebesar 106. Dari skor tersebut kemudian dibandingkan dengan hasil perhitungan rata-rata skor ideal $\left(\bar{x}_{i}\right)$ sebesar 48 ditambah 1,5 dikalikan dengan simpangan baku ideal $\left(S B_{i}\right)$ sebesar 16. Dari perhitungan tersebut menghasilkan total skor pembanding 72. Jadi, dapat disimpulkan bahwa, total skor (X) lebih besar dari total skor pembanding (106>72) dan masuk dalam kategori nilai A atau sangat baik.

\section{Hasil Analisis Validasi Produk oleh Siswa}

Angket validasi siswa berupa pernyataan dan pada setiap butir pernyataan akan diberi skor seperti pada tabel 3.6 pada metode penelitian. Data yang telah diperoleh melalui angket oleh siswa tersebut berupa nilai kuantitatif dan akan dihitung menggunakan SPSS yaitu untuk mengetahui $V$ alid Reliable dari data yang telah diperoleh. Data bisa dikatakan valid dan reliabel jika telah mencapai skor $>0,05$ (lebih dari 0,05). Berikut akan dicantumkan tabel hasil hitung SPSS Valid Reliable.

\begin{tabular}{|l|l|r|r|r|r|r|r|r|r|r|r|r|r|r|r|r|r|}
\hline \multirow{2}{*}{ Skor_Total } & $\begin{array}{l}\text { Pearson } \\
\text { Correlation }\end{array}$ & 24 & 49 & 53 & 69 & 46 & 69 & 44 & 49 & 65 & 44 & 59 & 45 & 68 & 49 & 39 & 58 \\
& 0 & $9^{*}$ & $8^{* *}$ & $9^{* *}$ & $6^{*}$ & $8^{* *}$ & $4^{*}$ & $9^{*}$ & $0^{* *}$ & $9^{*}$ & $0^{* *}$ & $6^{*}$ & $2^{* *}$ & $8^{*}$ & 5 & $0^{* *}$ \\
\hline
\end{tabular}

\begin{tabular}{|l|l|r|r|r|r|r|r|r|r|r|r|r|r|r|}
\hline Skor_Total & Pearson & 49 & 73 & 30 & 10 & 73 & 32 & 63 & 25 & 63 & 53 & 46 & 26 & 21 \\
& Correlation & $2^{*}$ & $2^{* *}$ & 7 & 7 & $4^{* *}$ & 5 & $0^{*}$ & $6^{* *}$ & $9^{* *}$ & $8^{*}$ & $9^{* *}$ & $3^{*}$ & $5^{*}$ \\
\hline
\end{tabular}

Berdasarkan penghitungan SPSS pada tabel 4.7 tersebut,dapat dilihat pada skor total Person Correlation menunjukkan semua skor telah mencapai lebih dari 0,05. Dengan demikian hasil analisis validasi produk oleh siswa telah dikatakan valid.

\section{Analisis Hasil Belajar (Pre-Test dan Post-Test)}

Pengaruh buku ajar yang dikembangkan oleh peneliti juga akan dianalisis dari hasil belajar siswa. Analisis ini diambil dari penghitungan Paired Sample T Test dengan menggunakan rumus 
SPSS. Setelah melalui penghitungan hasil data nilai pre-test dan post-test, akan diuji tingkat perbedaan sebelum dan setelah penggunaan buku ajar yang dikembangkan dengan menggunakan rumus penghitungan Paired Sample T Test pada SPSS berikut.

Tabel 4. Hasil analisis skala 5 atau lima kriteria ahli media Paired Samples Statistics

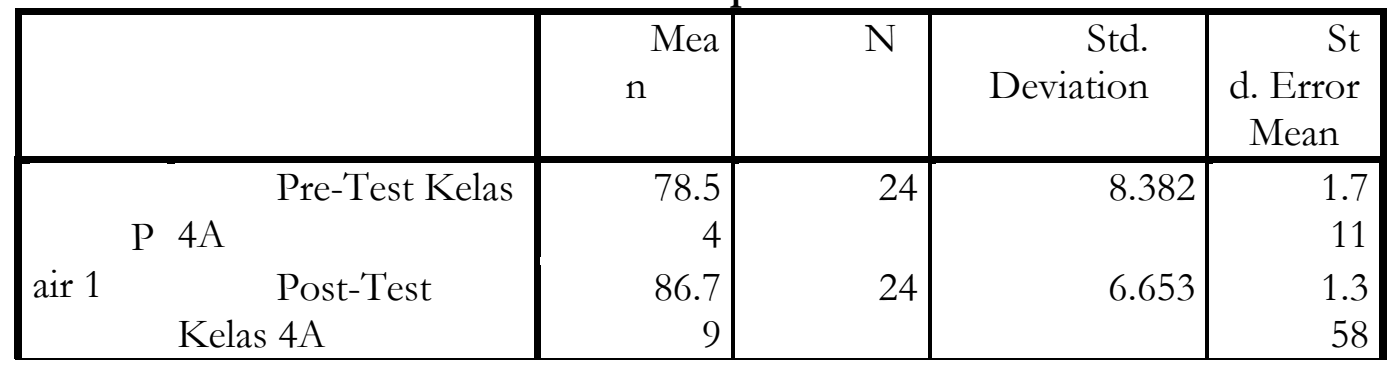

Pada tabel Paired Sample Statistic di atas, diketahui bahwa hasil rata-rata pada kolom Mean menunjukkan nilai rata-rata pre-test sebesar 78,54 sedangkan pada post-test menunjukkan nilai ratarata sebesar 86,79. Dari hasil tersebut dapat disimpulkan bahwa dari hasil pre-test dan hasil post-test telah mengalami kenaikan rata-rata nilai.

Tabel 5. Tabel Paired Sample Test

Paired Samples Test

\begin{tabular}{|c|c|c|c|c|c|c|c|c|}
\hline & \multicolumn{5}{|c|}{ Paired Differences } & $\mathrm{t}$ & \multirow{3}{*}{$\mathrm{f}$} & \multirow{3}{*}{$\begin{array}{l}\text { ig. } \\
(2- \\
\text { taile } \\
\text { d) }\end{array}$} \\
\hline & \multirow[t]{2}{*}{ ean } & \multirow[t]{2}{*}{$\begin{array}{c}\text { td. } \\
\text { Devia } \\
\text { tion }\end{array}$} & \multirow[t]{2}{*}{$\begin{array}{l}\text { Std } \\
\text {. Error } \\
\text { Mean }\end{array}$} & \multicolumn{2}{|c|}{$\begin{array}{c}95 \% \\
\text { Confidence } \\
\text { Interval of the } \\
\text { Difference }\end{array}$} & & & \\
\hline & & & & $\begin{array}{l}\mathrm{L} \\
\text { ower }\end{array}$ & pper & & & \\
\hline \begin{tabular}{ll} 
& \multicolumn{1}{c}{ Pre- } \\
& Test Kelas \\
& Eksperime \\
air 1 & $\mathrm{n}$ - Post- \\
& Test Kelas \\
& Eksperime \\
& $\mathrm{n}$
\end{tabular} & 8.250 & $\begin{array}{r}8 \\
.599\end{array}$ & $\begin{array}{r}1.7 \\
55\end{array}$ & 11.881 & 4.619 & 4.700 & 3 & 000 \\
\hline
\end{tabular}

Berdasarkan tabel tersebut telah diketahui bahwa Nilai signifikansi (2-tailed) adalah $\mathrm{p}=0.000$ ( $\mathrm{p}<0.05)$. Sehingga hasil pre-test dan post-test mengalami perubahan yang signifikan (berarti). Berdasarkan perhitungan dari pre-test dan post-test terbukti ada perbedaan yaitu hasil post-test lebih tinggi dari pada hasil pre-test. Sehingga dapat disimpulkan bahwa pengembangan buku ajar berbasis HOTS dimensi Taksonomi Bloom ini berpengaruh memberikan kenaikan pada nilai hasil belajar siswa.

\section{KESIMPULAN}

Tahap terakhir dari penelitian dan pengembangan 4-D Model adalah tahap penyebaran (Disseminate). Produk yang telah dikembangkan oleh peneliti telah melalui beberapa analisis validasi, diantaranya validasi oleh dosen ahli materi, guru mata pelajaran, dosen ahli media dan 
validasi oleh siswa setelah menggunakan buku ajar. Selain menggunakan penilaian melalui angket validasi, peneliti juga menggunakan analisis hasil pre-test dan post-test nilai siswa.

Berdasarkan semua hasil analisis tersebut, peneliti dapat menyimpulkan revisi produk ajar yang dikembangkan dengan mengacu 3 kriteria kelayakan bahan ajar yang diambil dari teori Nieveen. Berikut akan dijelaskan lebih rinci tentang 3 kriteria kelayakan tersebut.

Kevalidan dibedakan dalam dua hal yaitu relevansi dan konsistensi. Relevansi dan konsistensi bahan ajar diperoleh peneliti dari hasil validitas oleh ahli materi dan ahli media. Adapun hasil akhir dari analisis validasi dosen ahli materi mendapat total skor $(\mathrm{X})$ lebih besar dari total skor pembanding $(138>104,95)$ dan masuk dalam kategori nilai A atau sangat baik. Sedangkan analisis validasi oleh guru mata pelajaran mendapat total skor $(\mathrm{X})$ lebih besar dari total skor pembanding $(167>104,95)$ dan masuk dalam kategori nilai A atau sangat baik. Dan adapun analisis hasil validasi dari ahli media mendapat skor total, total skor (X) lebih besar dari total skor pembanding $(106>72)$ dan masuk dalam kategori nilai A atau sangat baik.

Berdasarkan hasil ketiga analisis validasi diatas, dapat disimpulkan bahwa buku ajar yang dikembangkan oleh peneliti sudah bisa dikategorikan memiliki kriteria valid untuk bisa digunakan. Kriteria kepraktisan ini diperoleh peneliti dari hasil angket validasi siswa setelah menggunakan bahan ajar. Selanjutnya validasi tersebut dihitung menggunakan SPSS yaitu untuk mengetahui Valid Reliable dari data yang telah diperoleh. Data bisa dikatakan valid dan reliable jika telah mencapai skor $>0,05$ (lebih dari 0,05).

Adapun hasil akhir dari penghitungan menggunakan SPSS diperoleh bahwa semua skor semua pernyataan mendapat poin lebih dari 0,05 dan sudah bisa dikatakan valid dan reliabel sebagaimana yang telah dijelaskan pada tabel 4.7 dan 4.8. Sehingga dapat disimpulkan bahwa buku ajar yang telah dikembangkan telah memenuhi kriteria praktis untuk bisa digunakan siswa.

Kriteria keefektifan ini diperoleh peneliti dari perbandingan hasil pre-test dan post-test siswa dengan menggunakan penghitungan Paired Sample T Test. Pada tabel Paired Sample Statistic di atas, diketahui bahwa hasil rata-rata pada kolom Mean menunjukkan nilai rata-rata pretest sebesar 78,54 sedangkan pada post-test menunjukkan nilai rata-rata sebesar 86,79. Sehingga dapat disimpulkan bahwa nilai post-test telah menunjukkan kenaikan dari rata-rata nilai pre-test. Sedangkan pada tabel Paired Sample Test diketahui bahwa Nilai signifikansi (2-tailed) adalah 0.000 $(\mathrm{p}<0.05)$. Sehingga hasil pre-test dan post-test mengalami perubahan yang signifikan (berarti).

Berdasarkan hasil penghitungan tersebut, dapat disimpulkan jika buku ajar yang dikembangkan oleh peneliti memberikan pengaruh pada hasil belajar siswa, sehingga dapat dikatakan buku ajar yang dikembangkan oleh peneliti sudah bisa memenuhi kriteria efektif. Dan buku ajar tersebut sebenarnya hanya bisa disebarkan untuk objek penelitian saja karena keterbatasan peneliti yang hanya meneliti satu masalah pada satu kelas di satu sekolah saja

\section{REFERENSI}

Abidin, Y. (2014). Desain sistem pembelajaran dalam konteks kurikulum 2013 (Cetakan kesatu). Refika Aditama.

Agustinus, H. (2014). Manajemen Kurikulum Berbasis Karakter: Konsep, Pendekatan dan Aplikasi. Alfabeta.

Agustyarini, Y., \& Jailani, J. (2015). Pengembangan bahan ajar matematika dengan pendekatan kontekstual dan metode penemuan terbimbing untuk meningkatkan EQ dan SQ siswa SMP Akselerasi. Jurnal Riset Pendidikan Matematika, 2(1), 135-147.

AS, A. (2017). Pengembangan Lembar Kerja Peserta Didik (LKPD) Berpikir Tingkat Tinggi pada Pokok Bahasan Sel Kelas XI IPA SMA Negeri 16 Makassar [PhD Thesis]. Universitas Islam Negeri Alauddin Makassar. 
Bahrissalim, B., \& Fauzan, F. (2018). Evaluasi Kurikulum Pelatihan Dalam Meningkatkan Kompetensi Pedagogik Guru Pai Di Balai Diklat Keagamaan Jakarta. Edukasia : Jurnal Penelitian Pendidikan Islam, 13(1), 25-52. https://doi.org/10.21043/edukasia.v13i1.2779

Fanani, A., \& Kusmaharti, D. (2018). Pengembangan pembelajaran berbasis HOTS (higher order thinking skill) di sekolah dasar kelas V. Jurnal Pendidikan Dasar, 9(1), 1-11.

Ibrahim, N. N., Ayub, A. F. M., \& Yunus, A. S. M. (2020). Impact of Higher Order Thinking Skills (HOTS) Module Based on the Cognitive Apprenticeship Model (CAM) on Student's Performance. International Journal of Learning, Teaching and Educational Research, 19(7), Article 7. http://www.ijlter.org/index.php/ijlter/article/view/2339

Katuuk, D. A. (2014). Manajemen Implementasi Kurikulum: Strategi Penguatanimplementasi Kurikulum 2013. Cakrawala Pendidikan, 1.

Kurniawan, D., \& Dewi, S. V. (2017). Pengembangan perangkat pembelajaran dengan media screencast-o-matic mata kuliah kalkulus 2 menggunakan model 4-D Thiagarajan. Jurnal Siliwangi Seri Pendidikan, 3(1).

Lestari, C. F., Kristiana, A. I., \& Kurniati, D. (2016). Pengembangan paket tes matematika berbasis kemampuan berpikir tingkat tinggi siswa kelas X TKJ SMK materi sistem persamaan linier. Jurnal Edukasi, 3(2), 34-38.

Lev, B., \& Thiagarajan, S. R. (1993). Fundamental information analysis. Journal of Accounting Research, 31(2), 190-215.

Maarif, M. A., \& Rofiq, M. H. (2018). Pola Pengembangan Kurikulum Pendidikan Pesantren Berkarakter: Studi Implementasi Pendidikan Berkarakter di Pondok Pesantren Nurul Ummah Mojokerto. 13, 16.

Permadi, B. A., \& Adityawati, I. A. (2018). Pengembangan Bahan Ajar Tematik Berbasis Islam \& Kearifan Lokal Kelas Iv Min Seduri \& Mis Nurul Amal Kabupaten Mojokerto. Nazhruna: Jurnal Pendidikan Islam, 1(1), 122-138. https://doi.org/10.31538/nzh.v1i1.61

Plomp, T., \& Nieveen, N. M. (2010). An introduction to educational design research: Proceedings of the seminar conducted at the East China Normal University, Shanghai (PR China), November 23-26, 2007. Stichting Leerplan Ontwikkeling (SLO).

Teti, T., Kosasih, E., \& Hamdu, G. (n.d.). Pengembangan Lembar Kerja Siswa Berbasis Hots Berdasarkan Taksonomi Bloom Di Sekolah Dasar. PED ADID AKTIKA: Jurnal Ilmiah Pendidikan Guru Sekolah Dasar, 5(3), 45-58.

Thiagarajan, S., \& And Others. (1974). Instructional Development for Training Teachers of Exceptional Children: A Sourcebook. Council for Exceptional Children, 1920 Association Drive, Reston, Virginia 22091 (Single Copy, \$5. https://eric.ed.gov/?id=ED090725 